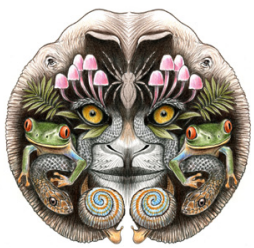

ISSN

Online 0974-7907

Print 0974-7893

OPEN ACCESS

\title{
DIVERSITY, THREATS AND CONSERVATION OF CATFISH FAUNA OF THE KRISHNA RIVER, SANGLI DISTRICT, MAHARASHTRA, INDIA
}

\author{
Suresh M. Kumbar ${ }^{1} \&$ Swapnali B. Lad ${ }^{2}$
}

1,2 Department of Zoology, Arts, Commerce and Science College, Palus, Sangli District, Maharashtra 416310, India ${ }^{1}$ smkumbar@rediffmail.com (corresponding author), ${ }^{2}$ swapnalilad33@yahoo.com

Abstract: The diversity of freshwater catfish species of the Krishna River, Sangli District was studied from June 2009 to July 2012. The study area covered $105 \mathrm{~km}$ from Karad City where the Koyna tributary joins the Krishna River up to Mhaishal, the state border of Maharashtra. It was divided into three streams for convenience, i.e., the upper stream starts from Karad and goes up to Takari, the middle stream from Takari to Bhilawadi and downstream from Bhilawadi to Mhaishal. A total of 13 species of catfish belonging to five families and 10 genera were recorded. The Bagridae family was dominant with six species, whereas Siluridae, Schilbidae and Clariidae had two species each and Sisoridae with one species. We have provided range extension for an endemic and threatened sisorid catfish Glyptothorax poonaensis. The occurrence and distribution of catfishes was more or less equal in number along the study area. The maximum number of species recorded was nine from the upper stream, whereas the middle and down streams had eight and seven species respectively. The distribution of catfish along the Krishna River system may be due to the slow and steady state water movement and its width that ensure the continuous availability of nutrition. It is suggested that the Krishna River would be a suitable habitat for the conservation of freshwater catfish if the threats are minimized.

Keywords: Catfish, checklist, conservation, Krishna River, threats.

The Krishna River is one of the major perennial rivers, which originates at Mahabaleshwar Hills $\left(17^{0} 58^{\prime} \mathrm{N}\right.$ \& $73^{\circ} 43^{\prime} \mathrm{E}$ ) in the Western Ghats of Maharashtra, at about $1337 \mathrm{~m}$ above sea level and flows as the Krishna River system across the whole width of the peninsula from west to east for a length of about $1400 \mathrm{~km}$ through the states of Maharashtra, Karnataka and Andhra Pradesh. Krishna River is a boon for all these three states and has made possible remarkable agricultural and industrial development. Moreover, it provides food and shelter to a large number of aquatic fauna. In Maharashtra, the major tributaries of Krishna River are Koyna, Yerla, Urmodi, Warna, Panchaganga, and Dudhganga.

The study area for the current investigation starts from Karad City where the Koyna tributary joins the Krishna River up to Mhaishal, the state border of Maharashtra. It receives an annual rainfall of about $300-500 \mathrm{~mm}$ from June-October and frequently undergoes drought and flooding. The maximum temperature reaches up to $41^{\circ} \mathrm{C}$ during summer and a minimum temperature of $10^{\circ} \mathrm{C}$ in winter. The type of vegetation is dry deciduous forest (Kumbar \& Patil 2010). The total study area covered approximately $105 \mathrm{~km}$ from Karad City to Mhaishal.

India, being a mega-diverse country, harbors 197 species of catfish (Jayaram 2009). In recent years much interest has developed in the study of the phylogeny and taxonomy of the order Siluriformes as a whole (Jayaram 2009). A lot of information has been accumulated in the field of diversity, density, threats and conservation

DOI: http://dx.doi.org/10.11609/JoTT.o3394.5362-7 | ZooBank: urn:Isid:zoobank.org:pub:A6E05DC9-D7DF-4CA0-B2A7-119B76E28323

Manuscript details: Ms \# o3394 | Received 18 October 2012 | Final received 16 November 2013 | Finally accepted 12 December 2013

Citation: Kumbar, S.M. \& S.B. Lad (2014). Diversity, threats and conservation of catfish fauna of the Krishna River, Sangli District, Maharashtra, India. Journal of Threatened Taxa 6(1): 5362-5367; http://dx.doi.org/10.11609/JoTT.03394.5362-7

Copyright: (C) Kumbar \& Lad 2014. Creative Commons Attribution 3.0 Unported License. JoTT allows unrestricted use of this article in any medium, reproduction and distribution by providing adequate credit to the authors and the source of publication.

Funding: University Grants Commission (UGC), Western Regional Office, Pune (No. F. 47-1718/10 (WRO).

Competing Interest: The authors declare no competing interests. Funding sources had no role in study design, data collection,

results interpretation and manuscript writing.

Acknowledgements: Authors are thankful to Dr. Satyawan S. Patil and Mr. Abhijit B. Ghadage, Department of Zoology, for their help in field work and support. We thank Management and Principal for providing laboratory facilities. We are thankful to Dr. Pankaj Bhatnagar, Officer-in-charge, and Dr. Shrikant Jadhav, Zoological Survey of India, Western Regional Center, Pune for confirmation of identified fish species and their suggestions for improving the manuscript. Miss. Swapnali B. Lad is thankful to Shivaji University, Kolhapur and SGM College Karad, for providing research laboratory facilities. SMK thanks the University Grants Commission, Western Regional Office, Pune for financial assistance to Minor Research Project. 
of freshwater fish fauna of the Krishna River system (Arunachalam 2000; Kharat et al. 2003, 2012; Dahanukar et al. 2004, 2012; Chandanshive et al. 2007; Sarwade \& Khillare 2010; Vijaylaxmi et al. 2010; Jadhav et al. 2011). Some studies on the diversity of fish fauna of Satara are also available. Silas (1953) studied the fish fauna of Mahabaleshwar and Wai in Satara District and recorded 14 species, recently Kharat et al. (2012) have given an updated checklist of fish fauna of the Krishna River at Wai and Dhom reservoir and reported the presence of 51 species. Annandale (1919) reported 18 species in Yenna River at Medha in Satara and Jadhav et al. (2011) reported 58 species in Koyna River. Although extensive surveys have been conducted in the Krishna River system (David 1963; Jayaram 1995) they did not provide a separate list of catfish species of the present study area. Recent reviews have highlighted a paucity of data on the fish fauna of the Western Ghats rivers (Kharat et al. 2003, 2012; Dahanukar et al. 2011b, 2012). Therefore, the present work was undertaken to determine the status, threats and conservation measures of catfish fauna of the Krishna River, Sangli District.

\section{Materials and Methods}

The catfish were collected in the Krishna River from Karad to Mhaishal which is approximately $105 \mathrm{~km}$ in length. The study area was divided into three streams for convenience i.e., upper, middle and down streams (Fig. 1). The study area included 13 collection sites (Karad, Bahe, Borgaon, Takari, Dudhondi, Amanapur, Burli, Ramanandnagar, Bhilwadi, Digraj, Sangli, Miraj, and Mhaishal) with inter point distance of 8-9 km. The

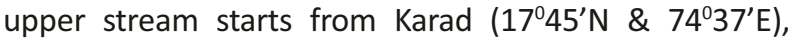
Satara District where the Koyna River joins the Krishna (Preeti Sangam) followed by Bahe, Borgaon, and Takari sites. The middle stream included Dudhondi, Amanapur, Burli, Ramanandnagar $\left(17^{\circ} 40^{\prime} \mathrm{N} \& 74^{\circ} 25^{\prime} \mathrm{E}\right)$, and Bhilwadi sites and Yerla tributary joins the Krishna near Sangli City on the left. Downstream includes Digraj, Sangli, Miraj and Mhaishal $\left(16^{\circ} 41^{\prime} \mathrm{N} \& 74^{\circ} 44^{\prime} \mathrm{E}\right)$ sites and two major

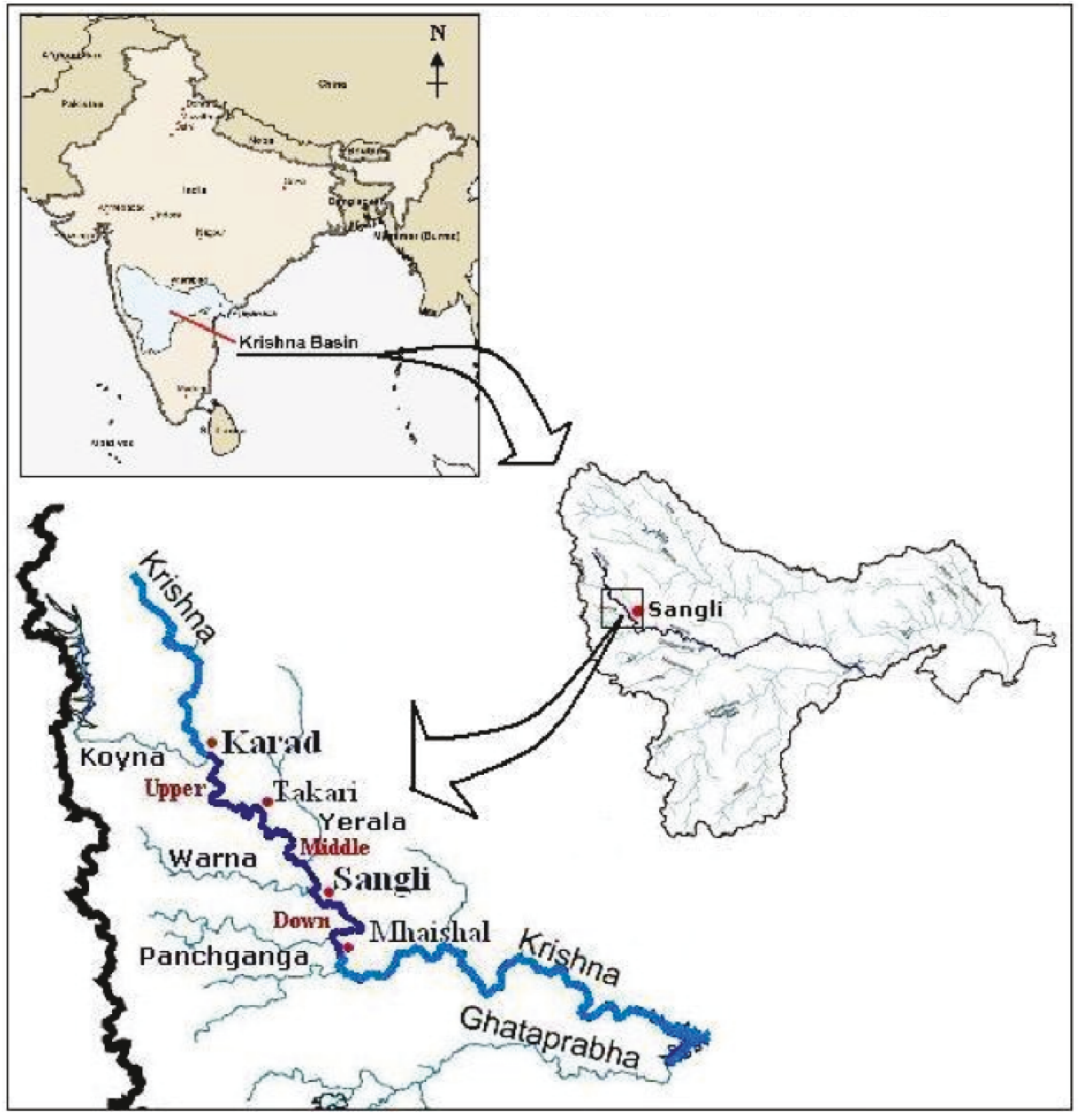

Figure 1. Study area showing upper, middle and down streams of the Krishna River 
tributaries, Warana and Panchaganga which join the Krishna at Haripur and Narsinh Wadi on the right side. Collections of catfish were made between 0600-1900 hr with the help of local fishermen by using different mesh sized nets, such as gill nets, cast nets and hooks etc. Alternatively, fish were also purchased from the fishermen on the spot and the local fish markets. The fish were categorized as common, moderate, and rare species on the basis of observation of the number of fishes in the total collection. Suitable sized specimens were selected from the collection, immediately photographed using digital SLR camera (Canon EOS - 1100D) and then fixed in $10 \%$ formalin. The specimens were brought to the laboratory and identified with the help of standard keys mentioned in the taxonomic literature i.e., Talwar \& Jhingran (1991), Jayaram (2009), and Jayaram (2010). The identified species were confirmed at Zoological Survey of India, Western Regional Centre, Pune. All identified specimens are deposited at the Department of Zoology, Arts, Commerce and Science College, Palus, Sangli District, Maharashtra, under the accession numbers from ZID 2032.

\section{Results}

In the present study 13 species of catfish belonging to five families and 10 genera of Siluriformes were collected from the Krishna River in Sangli District during the threeyear study period. The scientific name, family, collection sites and status of each catfish species is given in Table 1. A maximum of six species were recorded in the Bagridae family followed by two species in Siluridae, Schilbidae and
Clariidae and one species in Sisoridae (Table 1, Images 1a-m). The occurrence and distribution of catfish along the river was more or less equal with much overlapping within the species (Table 2, Fig. 2).

A maximum of nine species of catfish were recorded in the upper stream (Mystus seengtee, M. malabaricus, Rita gogra, R. kuturnee, Sperata seenghala, Proeutropiichthys taakree, Neotropius khavalchor, Wallago attu and Glyptothorax poonaensis), eight species in the middle ( $M$. seengtee, R. kuturnee, S. seenghala, Ompok bimaculatus, P. taakree, N. khavalchor, Heteropneustus fossilis, and Clarius gariepinus) and seven species in the downstream (M. seengtee, M. bleekeri, R. kuturnee, S. seenghala, W. attu, O. bimaculatus, and C. gariepinus) of the river. Species such as Mystus seengtee, $R$. kuturnee and $S$. seenghala (Fig. 2, Images 1a,e,f) were commonly observed in all the streams. The exotic species $C$. gariepinus (Image 11) was found in the middle and downstreams in moderate numbers.

Four species of catfish fall under the threatened and near threatened categories as per recent IUCN Redlist 2011. Among these, G. poonaensis (Image 1m) has been designated as Endangered (EN) species while $M$. malabaricus, W. attu and $O$. bimaculatus (Images $1 \mathrm{c}, \mathrm{g}, \mathrm{h}$ ) species have been considered as Near Threatened (NT). Abundance of these species populations was moderate to rare in the present study area of Krishna River. Neotropius khavalchor (Image 1j) has been considered as Data Deficient (DD) because of lack of substantial information for IUCN Red Listing.

Table 1. List of Catfish species collected from the Krishna River, Sangli District

\begin{tabular}{|c|l|l|l|c|l|}
\hline & Family & Species (Scientific name) & Abundance & $\begin{array}{c}\text { IUCN Redlist } \\
\text { Status }{ }^{\text {a }}\end{array}$ & Collection Sites \\
\hline 1 & Bagridae & Mystus seengtee (Sykes, 1839) & Moderate & LC & Bahe, Amnapur, Mhaishal \\
\hline 2 & Bagridae & Mystus bleekeri (Day, 1877) & Moderate & LC & Digraz \\
\hline 3 & Bagridae & Mystus malabaricus (Jerdon, 1849) & Moderate & NT & Karad, Bahe \\
\hline 4 & Bagridae & Rita gogra (Sykes, 1839) & Rare & LC & Karad, Miraj, Mhaishal \\
\hline 5 & Bagridae & Rita kuturnee (Sykes, 1839) & Common & $\begin{array}{l}\text { Bahe, Borgaon, Burli, Bhilwadi } \\
\text { station, Sangli, Mhaishal }\end{array}$ \\
\hline 6 & Bagridae & Sperata seenghala (Sykes, 1839) & Common & LC & Bahe, Ramanandnagar, Mhaishal \\
\hline 7 & Siluridae & Ompok bimaculatus (Bloch, 1794) & Common & NT & Dudhondi, Bhilwadi, Mhaishal \\
\hline 8 & Siluridae & Wallago attu (Bloch \& Schneider, 1801) & Rare & NT & Bahe \\
\hline 9 & Schilbidae & Proeutropiichthys taakree (Sykes, 1839) & Moderate & NE & Takari, Bahe, Bhilwadi \\
\hline 10 & Schilbidae & Neotropius khavalchor Kulkarni, 1952 & Moderate & DD & Karad, Dudhondi \\
\hline 11 & Clariidae & Heteropneustes fossilis (Bloch, 1794) & Rare & LC & Bhilavadi \\
\hline 12 & Clariidae & Clarias gariepinus (Burchell, 1822) & Rare & I & Mhaishal, Balwadi \\
\hline 13 & Sisoridae & Glyptothorax poonaensis Hora, 1938 & Rare & EN & Bahe \\
\hline
\end{tabular}

a Abbreviations: EN - Endangered, NT - Near Threatened, LC - Least Concern, NE - Not Evaluated, DD - Data Deficient; I - Introduced. 

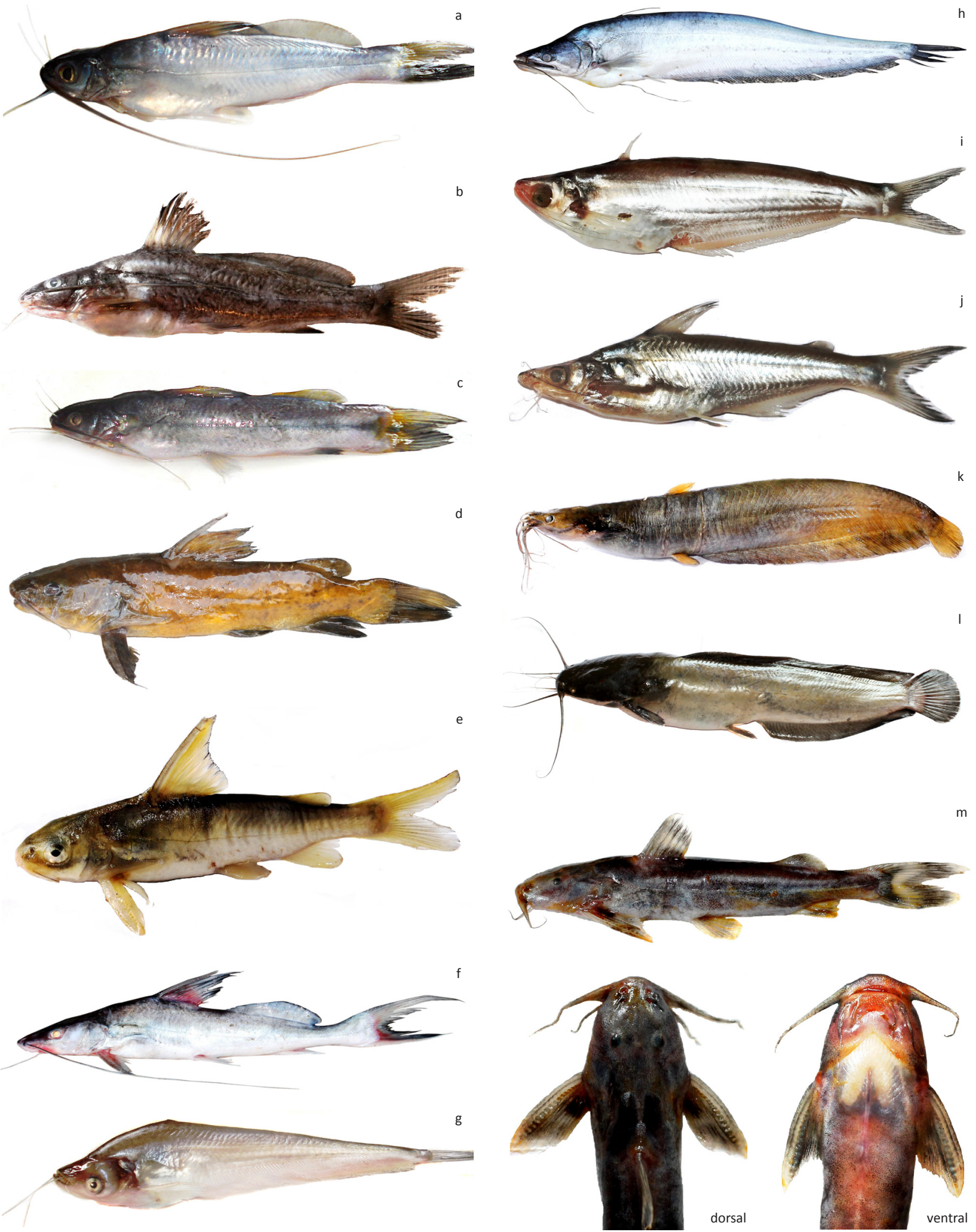

Images 1 a-m. Catfish images collected from the Krishna River Sangli District. @ S.M. Kumbar

a) Mystus seengtee; b) Mystus bleekeri; c) Mystus malabaricus; d) Rita gogra; e) Rita kuturnee; f) Sperata seenghala; g) Ompok bimaculatus;

h) Wallago attu; i) Proeutropiichthys taakree; j) Neotropius khavalchor; k) Heteropneustes fossilis; I) Clarius gariepinus; m) Glyptothorax poonaensis with dorsal and ventral profile. 


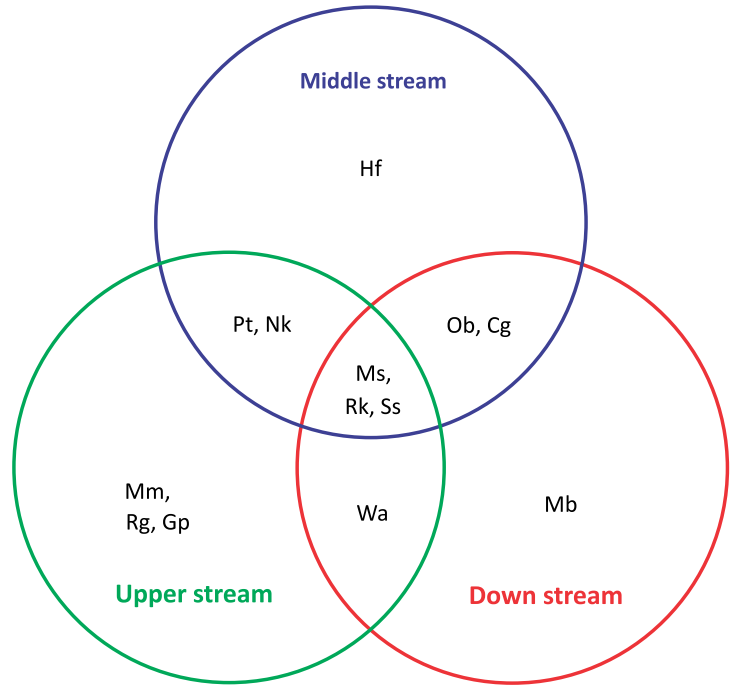

Figure 2. Venn diagram showing catfish species common and exclusive to the upper, middle and down streams of the Krishna River

Ms - Mystus seengtee; Mb - Mystus bleekeri; Mm - Mystus malabaricus; Rg - Rita gogra; Rk - Rita kuturnee; Ss - Sperata seenghala; Ob - Ompok bimaculatus; Wa - Wallago attu; Pt - Proeutropiichthys taakree; Nk - Neotropius khavalchor; Hf Heteropneustes fossilis; $\mathrm{Cg}$ - Clarius gariepinus; $\mathrm{Gp}$ - Glyptothorax poonaensis.

\section{Discussion}

The catfish diversity has been studied by different researchers in the country. For example, there are seven species in Karala River, West Bengal (Patra 2011), ten species in the wetlands of Shivamogga District, Karnataka (Kiran 2011) and 17 species in River Kelo and Mand in Raigharh District, Chhattisgarh, India (Tamboli \& Jha 2012). Although, a few studies are available on diversity and conservation of freshwater fish fauna of Krishna River system at Satara District, Kharat et al. (2012) reported six species of catfish, out of 51 species of freshwater fishes from Krishna River at Wai and Dhom reservoirs. Dahanukar et al. (2012) reported 11 species of catfish, out of 57 species of freshwater fishes of Indrayani River, a tributary of Bhima River. Jadhav et al. (2011) reported 10 species of catfish of a total 58 species, close to the present study area; their data is confined only to Koyna tributary which is a major tributary of Krishna, which joins it at Karad City. Our study area starts from Preeti Sangam and extends towards the east where Yerala, Warana and Panchaganga tributaries further join the Krishna River.

The present study has recorded 13 species of catfish which were spread evenly in the lotic system of Krishna River. Among them $G$. poonaensis is considered as Endangered (EN) species which was collected from the Bahe site near Islampur. The species is endemic to the northern Western Ghats and was only recently rediscovered after almost 70 years from Indrayani River, a tributary of Bhima
Table 2. Distribution of Catfish species in the upper, middle and down streams of the Krishna River, Sangli

\begin{tabular}{|c|l|c|c|c|}
\hline \multicolumn{1}{|c|}{ Species } & $\begin{array}{c}\text { Upper } \\
\text { stream }\end{array}$ & $\begin{array}{c}\text { Middle } \\
\text { stream }\end{array}$ & $\begin{array}{c}\text { Down } \\
\text { stream }\end{array}$ \\
\hline 1 & Mystus seengtee & + & + & + \\
\hline 2 & Mystus bleekeri & - & - & + \\
\hline 3 & Mystus malabaricus & + & - & - \\
\hline 4 & Rita gogra & + & - & - \\
\hline 5 & Rita kuturnee & + & + & + \\
\hline 6 & Sperata seenghala & + & + & + \\
\hline 7 & Ompok bimaculatus & - & + & + \\
\hline 8 & Wallago attu & + & - & + \\
\hline 9 & Proeutropiichthys taakree & + & + & - \\
\hline 10 & Neotropius khavalchor & + & + & - \\
\hline 11 & Heteropneustes fossilis & - & + & - \\
\hline 12 & Clarias gariepinus & - & + & + \\
\hline 13 & Glyptothorax poonaensis & + & - & - \\
\hline
\end{tabular}

+ indicates presence; - indicates absence

River of the Krishna River system (Dahanukar et al. 2011a). Our specimens resemble $G$. poonaensis redescribed by Dahanukar et al. (2011a), but further study, including molecular analysis, is necessary to validate the taxonomic status of this species available in Krishna River. The species is threatened by habitat modifications caused by dams, rapid development in urbanization and increasing pollution in this area (Dahanukar 2011a). Neotropius khavalchor, currently categorized under Data Deficient (Dahanukar 2011b), was collected from Karad, Satara District and Dudhondi, Sangli District. It is a very rare species and has been considered as threatened by Menon (2004) by suggesting that small changes in water quality is likely to have adverse effects and may result in the loss of this species. This species was reported by many ecologists in the Krishna River system. Panchaganga River near Kolhapur (Kulkarni 1952; Kalawar \& Kelkar 1956), Krishna River Islampur (Kulkarni 1952), Krishna River near Sangli (Jayaram 1995), Koyna River near Patan (Jadhav et al. 2011), Indrayani River near Kamshet (Dhanukar et al. 2012). In Karnataka it is known from Krishna River at Jamkhandi (Jayaram 1995), Tunga-Bhadra River (Shahnawaz \& Venkateshwarlu 2009) and in Eastern Ghats of Andhra Pradesh (Devi \& Indra 2003). However, due to a lack of substantive information about this species, it is considered as Data Deficient in the current IUCN Red List (Dahanukar 2011b).

Three species M. malabaricus, $W$. attu and $O$. bimaculatus are considered Near Threatened. The major threat is overexploitation of these species for food and has resulted in drastic population declines (Patra 2011). Threats also include anthropogenic activities such as, habitat loss due to sand mining, pollution and indirect mortality due to dynamite fishing in many parts of it's range (Abraham 
2011; Ng 2010; Ng et al. 2010). One exotic species $C$. gariepinus was observed in the middle and downstream of the river. This species might have been introduced to Krishna River system from the nearby aquaculture tanks/ ponds and moved through the tributaries which merge at middle and down streams. The even distribution of catfish along the Krishna River system may be due to the depth of water level that remains at 3-4 $\mathrm{m}$ even in summer which ensures the continuous availability of food and shelter while in monsoon the level rises up to 10-12 m. The slow and steady water movement and its width ensure the continuous availability of nutrition. In addition, the bottom of the river has rich fertile clay with varied aquatic flora and fauna. Hence, the present study suggests that the Krishna River system is a suitable habitat for the conservation of catfish.

The Krishna River is polluted due to discharge of industrial effluents, sewage runoff from the villages and cities which are situated on either sides of the river. Furthermore, unscientific practices such as dynamite fishing for collection of food fishes and sand mining are alarmingly increasing along the Krishna River system. If the present trend continues, the adverse conditions might lead to the loss of the fish fauna in the Krishna River system. Since the catfish form commercially important food fish and also our results suggest that the Krishna River is a more suitable habitat for the conservation of freshwater catfishes, there is a need to take up conservation measures in order to increase the fish population of the Krishna River system.

\section{References}

Abraham, R. (2011). Mystus malabaricus. In: IUCN 2012. IUCN Red List of Threatened Species. Version 2012.2. http://www.iucnredlist.org Downloaded on 30 March 2013.

Annandale, N. (1919). Bombay streams fauna: notes on fresh water fish mostly from the Satara and Poona Districts. Records of the Indian Museum 16: 125-138.

Arunachalam, M. (2000). Assemblage structure of stream fishes in the Western Ghats (India). Hydrobiologia 430: 1-31.

Chandanshive, N.E., S.M. Kamble \& B.E. Yadav (2007). Fish fauna of Pavana River of Pune Maharashtra. Zoos' Print Journal 22(5): 2693-2694; http:// dx.doi.org/10.11609/JoTT.ZPJ.1481.2693-4

Dahanukar, N. (2011a). Glyptothorax poonaensis. In: IUCN 2012. IUCN Red List of Threatened Species. Version 2012.2. <http://www.iucnredlist. org>. Downloaded on 21 March 2013.

Dahanukar, N. (2011b). Neotropius khavalchor. In: IUCN 2012. IUCN Red List of Threatened Species. Version 2012.2. <http://www.iucnredlist. org>. Downloaded on 21 March 2013.

Dahanukar, N., R. Raut \& A. Bhat (2004). Distribution, endemism and threat status of freshwater fishes in the Western Ghats of India. Journal of Biogeography 31: 123-293.

Dahanukar, N., M. Diwekar \& M. Paingankar (2011a). Rediscovery of the threatened Western Ghats endemic sisorid catfish Glyptothorax poonaensis (Teleostei: Siluriformes: Sisoridae). Journal of Threatened Taxa 3(7): 1885-1898; http://dx.doi.org/10.11609/JoTT.o2663.1885-98 Dahanukar, N., R. Raghavan, A. Ali, R. Abraham \& C.P. Shaji (2011b).
The status and Distribution of freshwater fishes of the Western Ghats. Chapter 3, pp. 21-48. In: Molur, S., K.G. Smith, B.A. Daniel \& W.R.T. Darwall (compilers). The Status and Distribution of Freshwater Biodiversity in The Western Ghats, India. IUCN, Cambridge, UK and Gland, Switzerland and Zoo Outreach Organisation, Coimbatore, India, $116 p p$.

Dahanukar, N., M. Paingankar, R.N. Raut \& S.S. Kharat (2012). Fish fauna of Indrayani River, northern Western Ghats, India. Journal of Threatened Taxa 4(1): 2310-2317; http://dx.doi.org/10.11609/JoTT.o2771.2310-7

Devi, K.R. \& T.J. Indra (2003). An updated checklist of the fishes of the ichthyofauna of Eastern Ghats. Zoos' Print Journal 18(4): 1067-1070; http://dx.doi.org/10.11609/JoTT.ZPJ.18.4.1067-70

David, A. (1963). Studies on fish and fisheries of the Godavari and Krishna river systems. Part 1. Proceedings of the National Academy of Science India 33(2) 263-293.

Jadhav, B.V., S.S. Kharat, N. Rupesh, R. Raut, N. Paingankar \& N. Dahanukar (2011). Fresh water Fish Fauna of Koyna River, Northen Westeren Ghats, India. Journal of Threatened Taxa 3(1): 1449-1455; http://dx.doi.org/10.11609/JoTT.o2613.1449-55

Jayaram, K.C. (1995). The Krishna River System: A Bioresources Study. Occasional papers No.160 Records of Zoological Society of India, 167pp.

Jayaram, K.C. (2009). Catfishes of India. Narendra Publishing House, Dehli, 383pp.

Jayaram K.C. (2010). The Fresh water Fishes of the Indian Region. Second Edition. Narendra Publishing House, Delhi, 616pp.

Kalawar, A.G. \& C.N. Kelkar (1956). Fishes of Kolhapur. Journal of the Bombay Natural History Society 53(4): 669-679.

Kharat, S.S., N. Dahanukar, R. Raut \& M. Mahabaleshwarkar (2003). Long term changes in freshwater fish species composition in North Western Ghats, Pune District. Current Science 84(6): 816-820.

Kharat, S.S., M. Paingankar \& N. Dahanukar (2012). Freshwater fish fauna of Krishna River at Wai, northern Western Ghats, India. Journal of Threatened Taxa 4(6): 2644-2652; http://dx.doi.org/10.11609/JoTT. O2796.2644-52

Kiran, B.R. (2011). Diversity, distribution and abundance of Murrels and Catfish resources in some wetlands of Karnataka, India. Asian Journal of Experimental Biological Sciences 2(2): 349-353.

Kulkarni, C. (1952). A new genus of schilbeid catfishes from the Deccan. Records of the Indian Museum 49: 231-238.

Kumbar, S.M. \& S.S. Patil (2010). Checklist and habitat of anuran species in the Sangli District, Maharashtra. Frogleg 14: 20-24.

Menon, A.G.K. (2004). Threatened Fishes of India and Their Conservation. Zoological Survey of India, Kolkata, 170pp.

Ng, H.H. (2010). Wallago attu. In: IUCN 2012. IUCN Red List of Threatened Species. Version 2012.2. <http://www.iucnredlist.org>. Downloaded on 21 March 2013.

Ng, H.H., K. Tenzin \& M. Pal (2010). Ompok bimaculatus. In: IUCN 2012. IUCN Red List of Threatened Species. Version 2012.2. <http://www. iucnredlist.org>. Downloaded on 30 March 2013.

Patra, A.K. (2011). Catfish (Teleostei: Siluriformes) diversity in Karala River of Jalpaiguri District, West Bengal, India. Journal of Threatened Taxa 3(3): 1610-1614; http://dx.doi.org/10.11609/JoTT.o2474.1610-4

Sarwade, J.P. \& Y.K. Khillare (2010). Fish diversity of Ujani wetland, Maharashtra, India. The Bioscan 1: 173-179.

Shahnawaz, A. \& M. Venkateshwarlu (2009). A checklist of fishes from the Tunga and Bhadra rivers, Karnataka, India with a special note on their biodiversity status. Current Biotica 3(2): 232-243.

Silas, E.G. (1953). Notes on the fishes from Mahabaleshwar and Wai (Satara District, Bombay State) Journal of the Bombay Natural History Society 51(3): 579-589.

Talwar, P.K. \& A.G. Jhingran (1991). Inland Fishes of India and Adjacent Countries. Oxford- IBH Publishing Co. Pvt. Ltd., New Delhi, 1158pp.

Tamboli, R.K. \& Y.N. Jha (2012). Status of catfish diversity of River Kelo and Mand in Raigarh District, CG, India. ISCA Journal Biological Scences 1: 71-73.

Vijaylaxmi, C., M. Rajshekhar \& K. Vijaykumar (2010). Freshwater fishes distribution and diversity status of Mullameri River, a minor tributary of Bheema River of Gulbarga District, Karnataka. International Journal of Systems Biology 2: 1-9. 